\title{
Improving the Cuttings Transport Performance of Water-based Mud Through the Use of Polypropylene Beads
}

(Meningkatkan Prestasi Pengangkutan Rincisan bagi Lumpur Dasar Air Menggunakan Manik Polipropilena)

\author{
M.D.U. ONUOHA, I. ISMAIL*, A. PIROOZIAN, N.S. MAMAT \& A.S. ISMAIL
}

\begin{abstract}
This research work presents the experimental results of the effect of polypropylene beads' concentrations in waterbased mud on wellbore cleaning. A comparative study of cuttings transport performance (CTP) of water-based mud and water-based mud with polypropylene beads were carried out at different hole angles of $0^{\circ}, 30^{\circ}, 60^{\circ} .75^{\circ}$ and $90^{\circ}$ in a $13 \mathrm{ft}(3.96 \mathrm{~m})$ acrylic concentric annulus flow test section, having a 2 in $(50.8 \mathrm{~mm})$ casing ID and a fixed 0.79 in $(20$ $\mathrm{mm}$ ) inner pipe OD. A total of 100 runs had been accomplished using fine sands (from Tanjung Balau, Johor Bahru, Malaysia), of size ranging from 5/127 - 6/127" (1.0 - $1.2 \mathrm{~mm})$ and density $2.4 \mathrm{~g} / \mathrm{cc}\left(2400 \mathrm{~kg} / \mathrm{m}^{3}\right)$, with the mud density and viscosity maintained at $9 \mathrm{ppg}\left(1078 \mathrm{~kg} / \mathrm{m}^{3}\right)$ and $5 \mathrm{cp}(0.005 \mathrm{~Pa} . \mathrm{s})$, respectively, in a flow velocity of $2.1 \mathrm{ft} / \mathrm{s}(0.64$ $\mathrm{m} / \mathrm{s})$. Polypropylene beads used in this study have the following properties: $290 \mathrm{~kg} / \mathrm{cm}^{2}$ of tensile strength at yield, 0.86 $\mathrm{g} / \mathrm{cc}\left(860 \mathrm{~kg} / \mathrm{m}^{3}\right)$ density, $4 \mathrm{~mm}$ (20/127") size, $82 \mathrm{R}$ scale Rockwell hardness, $13,500 \mathrm{~kg} / \mathrm{cm}^{2}$ flexural modulus, $85^{\circ} \mathrm{C}$ heat deflection temperature at $4.6 \mathrm{~kg} / \mathrm{cm}^{2}, 4 \mathrm{~g} / 10 \mathrm{~min}$ melt flow rate at $230^{\circ} \mathrm{C}$ and spherical in shape. The experimental findings showed that commingling the basic mud with polypropylene beads has successfully introduced a buoyant force which was found to have improved the cuttings transport performance by more than $10 \%$ when weight concentration of the polypropylene beads was increased to $1.5 \%$ as compared with the performance obtained from the basic water-based mud. The improvement of cuttings transport performance was found to be more significant in a vertical hole.
\end{abstract}

Keywords: Cuttings transport performance; drilled cuttings; drilling mud; polypropylene beads; water-based mud

ABSTRAK

Penyelidikan ini mengenengahkan hasil kajian tentang kesan kepekatan berat manik polipropilena dalam lumpur dasar air terhadap pembersihan lubang telaga. Suatu kajian perbandingan terhadap prestasi pengangkutan rincisan bagi lumpur dasar air bercampur dengan manik-manik polipropilena berbanding lumpur dasar air tanpa manik polipropilena telah dijalankan pada sudut lubang yang berbeza, iaitu $0^{\circ}, 30^{\circ}, 60^{\circ}, 75^{\circ}$ dan $90^{\circ}$. Kajian melibatkan penggunaan paip akrilik sepanjang $13 \mathrm{kaki}(3.96 \mathrm{~m}$ ) yang memiliki bahagian ujian aliran anulus sepusat, yang terdiri daripada satu selongsong berdiameter dalam 2 in $(50.8 \mathrm{~mm}$ ) dan satu paip dalaman tak putar berdiameter luar $0.79 \mathrm{in}(20 \mathrm{~mm})$. Sebanyak 100 uji kaji telah dijalankan menggunakan pasir halus dari Tanjung Balau, Johor Bahru, Malaysia, yang bersaiz 5/127 - 6/127" $(1.0-1.2 \mathrm{~mm})$ dan berketumpatan $2.4 \mathrm{~g} / \mathrm{cc}\left(2400 \mathrm{~kg} / \mathrm{m}^{3}\right)$. Lumpur gerudi yang digunakan berketumpatan 9 ppg $(1078$ $\left.\mathrm{kg} / \mathrm{m}^{3}\right)$ dan berkelikatan $5 \mathrm{cp}(0.005 \mathrm{~Pa} . \mathrm{s})$, dengan purata halaju aliran di dalam paip ialah $2.1 \mathrm{ka} / \mathrm{s}(0.64 \mathrm{~m} / \mathrm{s})$. Manikmanik polipropilena yang digunakan dalam kajian mempunyai sifat-sifat berikut: Kekuatan tegangan, ketumpatan 0.86 $\mathrm{g} / \mathrm{cc}\left(860 \mathrm{~kg} / \mathrm{m}^{3}\right)$, saiz $4 \mathrm{~mm}(20 / 127 ")$, kekerasan $82 \mathrm{R}$ pada skala Rockwell, modulus lenturan 13,500 kg/ $\mathrm{cm}^{2}, \mathrm{suhu}$ pesongan haba $85^{\circ} \mathrm{C}$ pada $4.6 \mathrm{~kg} / \mathrm{cm}^{2}$, kadar alir leburan $4 \mathrm{~g} / 10 \mathrm{~min}$ pada $230^{\circ} \mathrm{C}$ dan berbentuk sfera. Hasil kajian menunjukkan bahawa campuran lumpur dasar air dengan manik-manik polipropilena berjaya menghasilkan suatu daya apung. Daya ini telah meningkatkan prestasi pengangkutan rincisan melebihi $10 \%$ apabila kepekatan berat manik polipropilena ditingkatkan kepada $1.5 \%$ berbanding prestasi lumpur dasar air tanpa manik polipropilena. Peningkatan prestasi pengangkutan rincisan adalah lebih ketara dalam lubang tegak.

Kata kunci: Lumpur dasar air; lumpur gerudi; manik polipropilena; prestasi pengangkutan rincisan; rincisan gerudi

\section{INTRODUCTION}

Over the years, drilling operations have been an indispensable aspect of oil and gas exploration and field development. A well designed drilling program will not only reduce the drilling cost and rig time, but would as well increase its presumed economic benefits during exploitation through mitigation of complications and damages to the targeted zones.

On the strength of this premise, it is worthwhile to say that a proper understanding of all the influential parameters that affect drilled cuttings transport and consequent hole cleaning for an effective drilling process would be very 
useful. However, previous researchers have done great works in unravelling the rationale behind the factors that affect the cuttings carrying capacity of drilling fluids. Parameters such as annular flow rate, rate of penetration, fluid density, effective fluid viscosity, cuttings size, cuttings density, well inclination and pipe/hole eccentricity play leading roles in cuttings transport performance of drilling fluid (Ozbayoglu et al. 2004; Stan \& Avram 2014). In the same vein, other factors such as fluid flow regime and pipe rotation have also been observed to have a great impact on drilled cuttings transport in vertical, deviated, and horizontal wellbores (Ford et al. 1990; Ozbayoglu et al. 2008; Rooki et al. 2014; Tomren et al. 1986).

Due to the imperative nature of deviating a well directionally or horizontally during drilling operations, as desired in order to bypass many obstructions and to reach the targeted zones for an economic exploitation of oil and gas reserves, the petroleum industry has witnessed continuous research work for the improvement of the hole cleaning capabilities of the drilling fluids for an effective and efficient drilling operation. Thus, if drilling programs are not properly structured, its inherent problems such as excessive torque and drag, pipe sticking, increase in equivalent circulation density, resistance in drill string sliding, lost circulation, barite sag, difficulty in running casing and logging tools would prevail (Ali et al. 2012; Cameron 2001). However, these problems as aforementioned are most prevalent when deviating a wellbore along a planned target at a given lateral distance and direction from vertical. Therefore, this paper discusses a new idea that has been realized in the form of using polypropylene beads, an inert material that would not alter the chemistry of the drilling mud when commingled together to improve the cuttings transport capacity of water-based mud.

\section{EXPERIMENTAL SETUP AND MATERIALS}

\section{EXPERIMENTAL FLOW-LOOP}

The experimental flow-loops shown in Figure 1, was designed and developed to satisfy the objective of this research work, which was to investigate the effect of polypropylene bead's weight concentrations in waterbased mud would have on wellbore cleaning for the vertical, inclined and horizontal conditions of the annulus test section (i.e. the simulated wellbore). The components of the flow-loop comprised a concentric annulus test section of $13 \mathrm{ft}$ (3.96 m) long acrylic pipe, with 2-in (50.8 $\mathrm{mm})$ ID for the outer pipe and $0.79 \mathrm{in}(20 \mathrm{~mm})$ OD for the fixed inner pipe with both ends closed. The annulus test section was designed to allow the variation of its angles, which provided the means of investigating the effect of hole inclination angles (i.e. $0^{\circ}, 30^{\circ}, 60^{\circ}, 75^{\circ}$ and $90^{\circ}$ ) on the performance of the commingled polypropylene beads and water-based mud for cuttings transport. The mud was circulated using a 2-hp variable speed centrifugal pump which was connected to 132.1 gallons (500 L) capacity

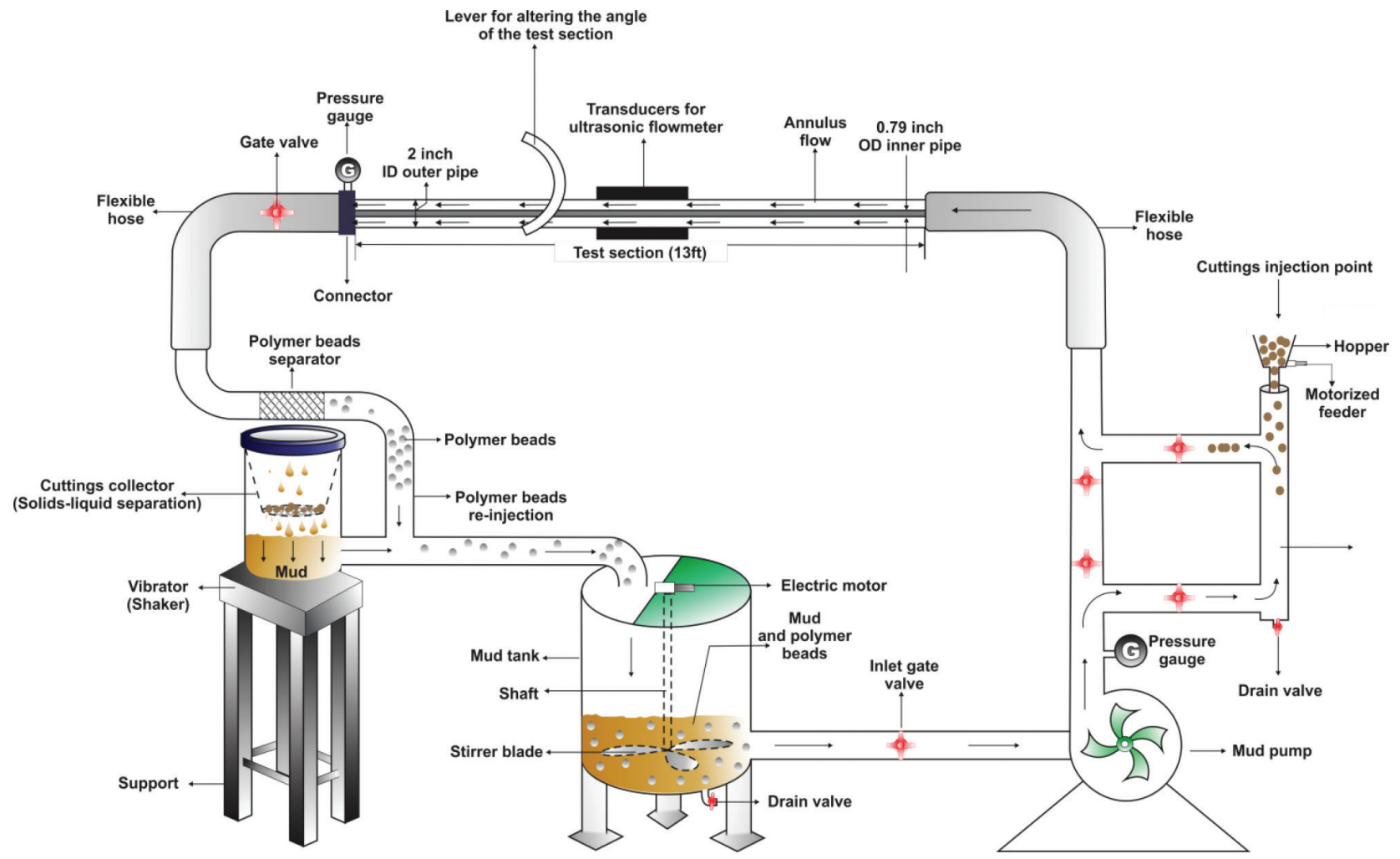

FIGURE 1. Experimental flow-loop 
mud tank. Two separation systems were incorporated in the system to allow the separation of polypropylene beads from transported cuttings and mud using a $2 \mathrm{~mm}$ mesh separator; and the separation of transported drilled cuttings and mud using a cuttings collector fitted with mesh.

\section{SIMULATED DRILLED CUTTINGS}

Fine sands were used as solid particles or simulated drilled cuttings for this study, which was taken from Tanjung Balau Beach, Johor Bahru, Malaysia. The particles size was in the range between 5/127 - 6/127 (1.0-1.2 mm) and of irregular shapes with density $2.4 \mathrm{~g} / \mathrm{cc}\left(2400 \mathrm{~kg} / \mathrm{m}^{3}\right)$ as was determined using the standard ASTM D4253-00 (2006) testing method.

\section{DRILLING MUD}

American Petroleum Institute (2009) recommended practices were followed in the preparation of the waterbased mud that was used in this research work. Bentonite was used as the viscosifier, barite as the weighting agent, and tap water as the continuous phase. However, in order to establish a justified basis for comparison between water-based mud containing different weight concentrations of polypropylene beads and a water-based basic mud for cuttings transport performance evaluation, the rheological properties were measured and kept constant throughout the experiment. Table 1 shows the components of the basic mud (i.e. laboratory scale) and the components of the basic mud with polypropylene beads of different weight concentrations that were used in accomplishing the research work. It can be seen that the proportion of barite requirement was increased slightly for different concentrations of polypropylene beads in the water-based mud because the introduction of the polypropylene beads has reduced the mixture density of the mud when blended together due to its light weight that is less dense than water. The addition of barite has successfully kept the density and mud rheology constant in all the runs.

\section{POLYPROPYLENE BEADS}

Mass produced polypropylene-based polypropylene beads (PP) (Figure 2) were used in this research work, which have regular sizes of 0.16 " $(4 \mathrm{~mm})$ and are of spherical in shape with density as determined via the ASTM D425300 (2006) testing method. To prepare the desired waterbased muds with polymer beads, three weight percentages of polypropylene beads $(0.5,1.0$ and $1.5 \mathrm{wt}$. \%) were applied. The Differential Scanning Calorimeter (DSC) test conducted on both polypropylene beads showed that Polypropylene beads has a melting point temperature $\left(T_{m}\right)$ of while Polyethylene polypropylene beads is thus enables Polypropylene polymers to be widely used in drilling operations including oilfields in Malaysia. However, the polypropylene-based polymer beads as being an inert material has no chemical properties.

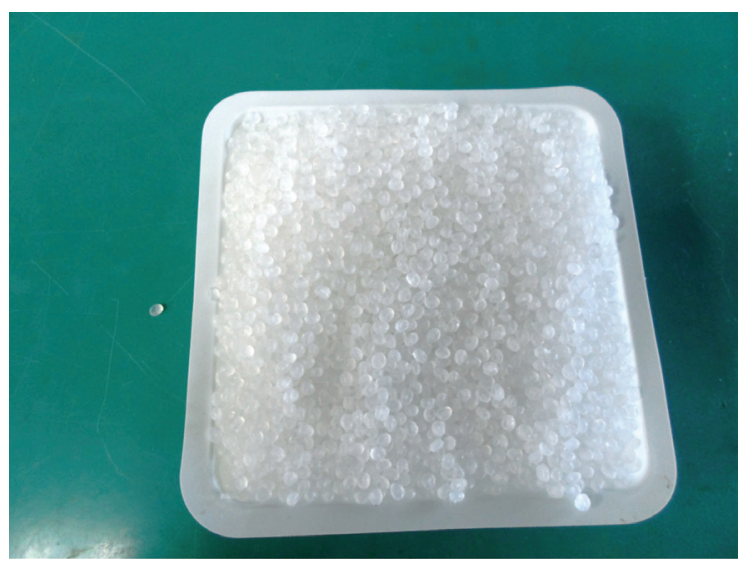

FIGURE 2. Polypropylene beads

TABLE 1. Formulations of drilling muds used in the current study

\begin{tabular}{|c|c|c|c|c|c|c|}
\hline \multirow[t]{2}{*}{ Type of drilling mud } & \multirow[t]{2}{*}{ Components } & \multicolumn{5}{|c|}{ Rheological Properties } \\
\hline & & $\begin{array}{l}\mu_{a} \\
\mathrm{cp}\end{array}$ & $\begin{array}{l}\mu_{p} \\
\mathrm{cp}\end{array}$ & $\begin{array}{c}\rho \\
\text { ppg }\end{array}$ & $\begin{array}{c}\mathrm{YP} \\
\mathrm{lb} / 100^{2}\end{array}$ & $\begin{array}{c}\mathrm{GS} \\
\mathrm{lb} / 100 \mathrm{ft}^{2} @ \\
10 \mathrm{~s}-10 \mathrm{~m}\end{array}$ \\
\hline Basic water-based mud & $\begin{array}{l}\text { Barite }(110.5 \mathrm{~g})+\text { bentonite }(40 \mathrm{~g}) \\
+ \text { tap water }(1400 \mathrm{~mL})\end{array}$ & 7 & 5 & 9 & 4 & $2-15$ \\
\hline $\begin{array}{l}\text { Water-based mud with } 0.5 \\
\text { wt. } \% \text { of polypropylene } \\
\text { beads }\end{array}$ & $\begin{array}{l}\text { Barite }(119 \mathrm{~g})+\text { bentonite }(40 \mathrm{~g}) \\
+ \text { polypropylene Beads }(7.75 \mathrm{~g}) \\
\text { tap water }(1400 \mathrm{~mL})\end{array}$ & & & & & \\
\hline $\begin{array}{l}\text { Water-based mud with } 1.0 \\
\text { wt. } \% \text { of polypropylene } \\
\text { beads }\end{array}$ & $\begin{array}{l}\text { Barite }(121.56 \mathrm{~g})+\text { bentonite }(40 \mathrm{~g}) \\
\text { + polypropylene Beads }(15.5 \mathrm{~g}) \\
\text { tap water }(1400 \mathrm{~mL})\end{array}$ & 7 & 5 & 9 & 4 & $2-15$ \\
\hline $\begin{array}{l}\text { Water-based mud with } 1.5 \\
\text { wt. } \% \text { of polypropylene } \\
\text { beads }\end{array}$ & $\begin{array}{l}\text { Barite }(124.21 \mathrm{~g})+\text { bentonite }(40 \mathrm{~g}) \\
+ \text { polypropylene beads }(23.25 \mathrm{~g}) \\
\text { tap water }(1400 \mathrm{~mL})\end{array}$ & 7 & 5 & 9 & 4 & $2-15$ \\
\hline
\end{tabular}




\section{EXPERIMENTAL METHODS}

The sand particles were sieved to the desired sizes and weighed into separate masses of $200 \mathrm{~g}(0.2 \mathrm{~kg})$ each to serve as the test solid samples for different runs. The basic water-based mud of density $9 \mathrm{ppg}\left(1078 \mathrm{~kg} / \mathrm{m}^{3}\right)$ and viscosity $5 \mathrm{cp}$ (0.005 Pa.s) was then prepared in the mud tank as the drilling fluid. Mud circulation was done at ambient condition of $28^{\circ} \mathrm{C}$ using a variable speed centrifugal pump and it continued until a stabilized fluid flow rate was achieved as measured by an ultrasonic flow meter. A constant flow velocity of $2.1 \mathrm{ft} / \mathrm{s}(0.64 \mathrm{~m} / \mathrm{s})$ and flow rate of $17 \mathrm{gal} / \mathrm{min}$ (64 1/min) were maintained throughout the runs. Once the stable flow velocity was reached, the sand particles meant to be transported were injected into the system at an injection rate of $0.44 \mathrm{lbm} /$ $\min (200 \mathrm{~g} / \mathrm{min})$ and the test period lasted for $6 \mathrm{~min}$. The transported cuttings were collected, washed, dried and weighed in order to ascertain the actual mass of sands that were successfully transported through the concentric annulus test section, which indicated the cuttings carrying capacity of the test mud and otherwise known as the cuttings transport performance. The same procedure was repeated at different inclination angles of the annulus test section (i.e. $30^{\circ}, 60^{\circ}, 75^{\circ}$ and $90^{\circ}$ ).

After all the runs have been made with the basic waterbased mud, hence polypropylene beads of different weight concentrations (i.e. $0.5,1.0$ and $1.5 \%$ ) were introduced into the said mud while the rheological properties were maintained constant to ensure conformity of both muds. The experiment was repeated by commingling the polypropylene beads with the mud as mentioned above, as such to ascertain its cuttings transport performance and comparison was made to that of the basic water-based mud to ascertain efficiency. The equation used to calculate the cuttings transport ratio (CTR) is given by (1) and a total of 100 runs were accomplished.

$$
\text { Cutting transport ratio }(\%)=\frac{\text { Final dried weight }}{\text { Initial dried weight }} \times 100 \text {. }
$$

\section{RESULTS AND DISCUSSION}

\section{EFFECT OF POLYPROPYLENE BEADS}

Considering only $0.5 \mathrm{wt} . \%$ concentration of polypropylene beads in the basic water-based mud prepared, it can be seen from Figure 3 that the cuttings transport ratio (CTR) was $88 \%$ as compared to that of basic water-based mud of $82 \%$ for the vertical position (i.e. $0^{\circ}$ ) of the test section. Moving further at the respective hole inclination angles investigated, mud with polypropylene beads was also observed to have performed better in cuttings lifting than that of the basic water-based mud. This outstanding performance has shown that if polypropylene beads were to be commingled with drilling fluid in any drilling operations, it would enhance the cuttings transport and invariably improve the effectiveness of the wellbore cleaning by the transporting fluid. The improvement recorded by the drilling mud with polypropylene beads has been influenced by two major forces that act on slipping cuttings of imperfect sphere in a turbulent flow, namely the gravitational and drag forces (Clark \& Bickham 1994; Duan et al. 2007; Skalle 2011).

Generally, the presence of the polypropylene beads in the water-based mud has successfully reduced the slipping velocity of the drilled cuttings due to its buoyancy in the mud, which consequently reduces the Reynolds number of the particles and as such, if the Reynolds number of the slipping particles is reduced, invariably the coefficient of drag would increase (Skalle 2011). If the coefficient of drag is increased, a higher drag force would be experienced in the transporting fluid and thereby enhancing the cuttings carrying capacity of the mud for a better wellbore cleaning in vertical, deviated and horizontal conditions of the hole.

\section{EFFECT OF INCREASE IN POLYPROPYLENE BEADS CONCENTRATIONS}

Figure 4 shows that increasing the weight concentrations of the polypropylene beads resultantly increased the

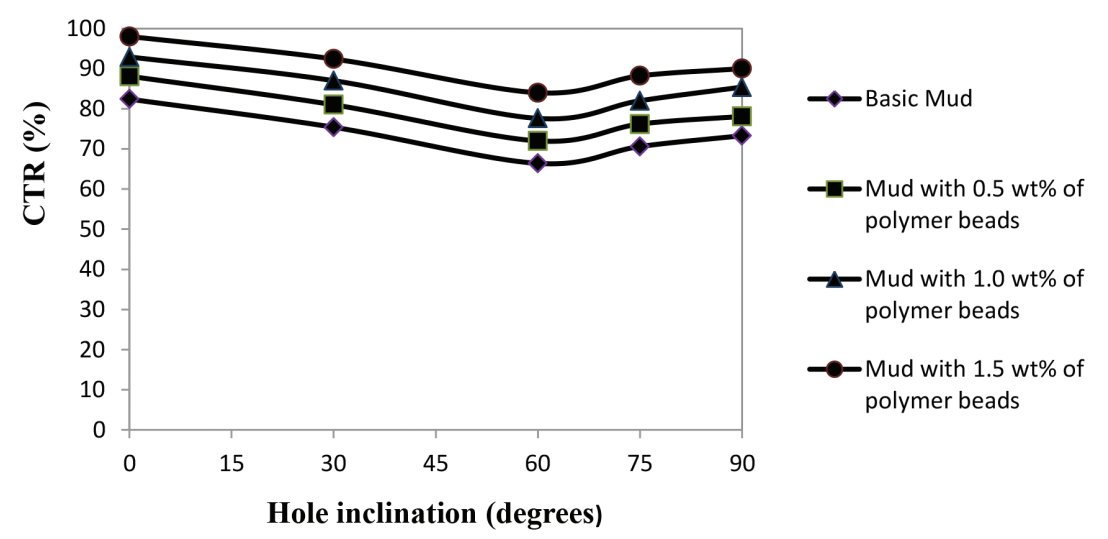

FIGURE 3. Cuttings transport performance for respective muds 
cuttings transport performance of the mud by more than $10 \%$ (i.e. cuttings transport ratio of $98 \%$ at 1.5 wt. $\%$ of polypropylene beads as compared to $87 \%$ at $0.5 \mathrm{wt} . \%$ in a vertical hole). Furthermore, Figure 5 shows the cuttings transport ratio comparison for the incremental changes in the weight concentrations of polypropylene beads used. It was observed that at $75^{\circ}$ inclination angle of the test section, all the various incremental changes in the concentrations of the polypropylene beads were found to have transported the drilled cuttings at an average incremental rate of $7 \%$ as can be seen at the intersection of the three curves.

\section{EFFECT OF HOLE INCLINATION ANGLE}

The cuttings transport ratio was found to have decreased (Figure 3) when the wellbore was deviated from the vertical to the near vertical plane (i.e. $0^{\circ}-30^{\circ}$ ). This was inferred to have caused by a high impact of gravity acting on the sliding bed which led to the increase in cuttings concentrations on the lower end of the annulus. At this juncture, it is pertinent to say that this research work has demonstrated credence and the observed critical angle at $60^{\circ}$ is in consonant with that observed by Binzanti et al. (2003), Brown et al. (1989), Ford et al. (1990), Ogunride \& Dosunmu (2012), Ozbayoglu et al. (2008), Peden et al. (1990), Sifferman \& Becker (1992) and Tomren et al. (1986).

Dramatically, the declining performance of the transporting fluid reversed gradually as the hole inclination angle was changed from the near horizontal to the horizontal plane $\left(75^{\circ}-90^{\circ}\right)$. This was due to the cuttings bed being less moveable as the impact of gravity was less felt. Figure 4 shows that inclination angle of $60^{\circ}$ had the lowest cuttings transport ratio, followed progressively by $75^{\circ}, 90^{\circ}, 30^{\circ}$ and finally $0^{\circ}$ (vertical). Though hole inclination angle impacted significantly on the cuttings transport performance of the drilling mud, but the presence of polypropylene beads has demonstrated a leverage in improving the cuttings carrying capacity of the water-based mud in spite of the enormous challenges imposed by hole angles.

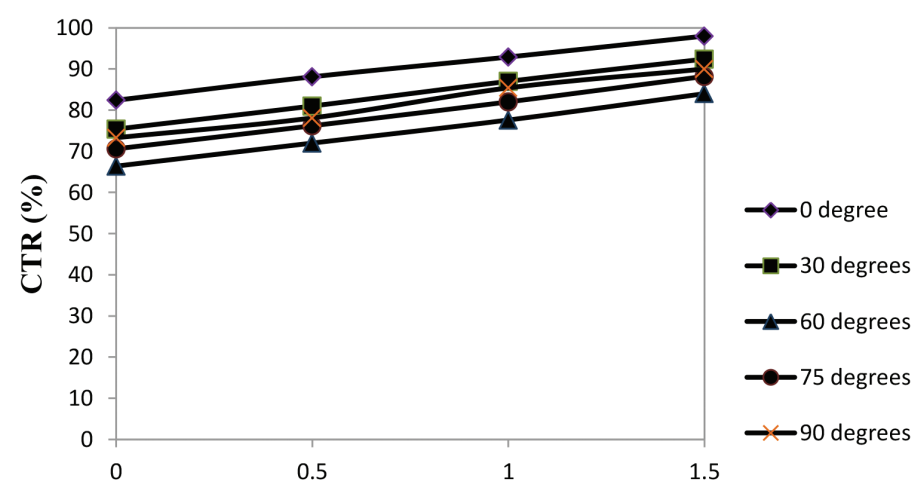

Concentration of polypropylene beads (wt\%)

FIGURE 4. Cuttings transport ratio against weight concentration of polypropylene beads in the water-based mud

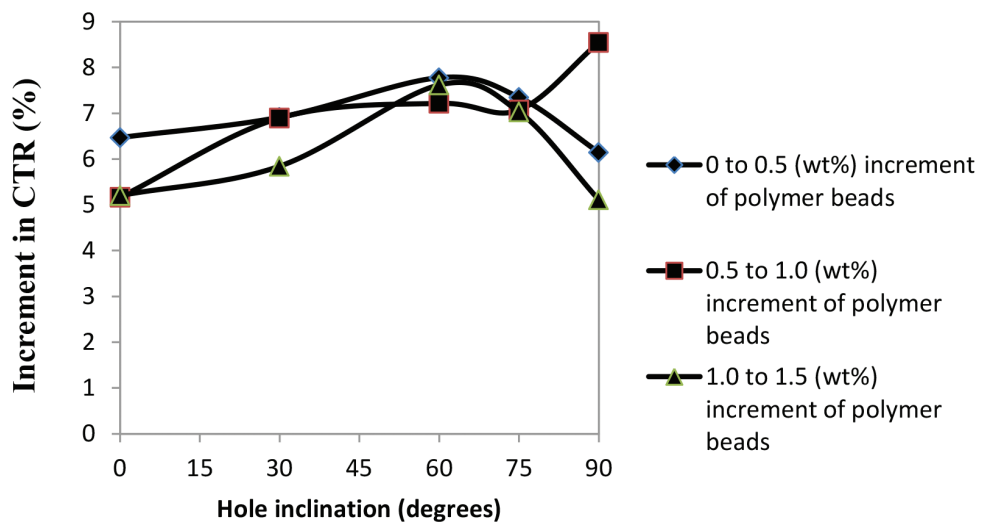

FIGURE 5. Incremental cuttings transport ratio against incremental changes in wt. \% of polypropylene beads 


\section{CONCLUSION}

The experimental parameters were borne of simulating for feasible field values and that used by other investigators. Commingling polypropylene beads with water-based mud has improved the cuttings transport performance of the said mud, Increasing the weight concentrations of the polypropylene beads would improve the cuttings transport performance of the said mud. Though hole inclination angle has a significant impact on cuttings transport in deviated wells, but mud with varying weight concentrations of polypropylene beads has fared well in the hole angles investigated as compared to that of basic mud, which shows that commingling polypropylene beads with the mud would offer better wellbore cleaning in drilling highly deviated or horizontal wells. The polypropylene beads being an inert and non-toxic material is environmentally friendly and could be washed, stored, and re-used for subsequent drilling operations, thereby cutting down overhead cost and improving the contractor's economic value.

\section{ACKNOWLEDGEMENTS}

The authors wish to express their profound gratitude to Universiti Teknologi Malaysia and The Ministry of Education, Malaysia in particular, for providing the needed fund via Fundamental Research Grant Scheme (FRGS: 4F575) and facilities that saw the success of this research work.

\section{REFERENCES}

Ali, P., Issham, I., Zulkefli, Y., Parham, B. \& Ahmad, S. 2012. Impact of drilling fluid viscosity, velocity and hole inclination on cuttings transport in horizontal and highly deviated wells. J. Petrol. Explor. Prod. Technol. 2: 149-156.

American Petroleum Institute (API). 2009. Recommended Practices for Field Testing Water-Based Drilling Fluid. (API-RP-13B-1). 4th ed. Dallas: API.

Bizanti, M.S. \& Alkafeef, S.F. 2003. A Simplified Hole Cleaning Solution to Deviated and Horizontal Wells. SPE 106707.

Brown, N.P., Bern, P.A. \& Weaver, A. 1989. Cleaning deviated holes: New experimental and theoretical studies. Paper SPE/IADC18636 presented at the 1989 SPE/IADC Drilling Conference, New Orleans, February 28-March 3.

Cameron, C. 2001. Drilling fluids design and management for extended reach drilling. Paper presented at the SPE/IADC Middle East Drilling Technology Conference, Bahrain, Jan.

Clark, R.K. \& Bickham, K.L. 1994. A Mechanistic Model for Cuttings Transport. SPE 28306
Duan, M., Miska, S., Yu, M., Takach, N. \& Ahmed, R. 2007. Critical Condition for Effective Sand-Sized Solids Transportation in Horizontal and High-Angle Wells. SPE 106707.

Ford, J.T., Peden, J.M., Oyeneyin, M.B., Gao, E. \& Zarrough, R. 1990. Experimental Investigation of Drilled Cuttings Transport in Inclined Boreholes. SPE 20421.

Ogunrinde, J.O. \& Dosunmu, A. 2012. Hydraulics Optimization for Efficient Hole Cleaning in Deviated and Horizontal Wells. SPE 162970.

Ozbayoglu, M.E., Saasen, A., Sorgun, M. \& Svanes, K. 2008. Effects of Pipe Rotation on Hole Cleaning for Water Based Drilling Fluids in Horizontal and Deviated Wells. IADC/ SPE 114965

Ozbayoglu, M.E., Miska, S.Z.\& Takach, N. 2004. Analysis of the Effects of Major Drilling Parameters on Cuttings Transport Efficiency for High-Angle Wells in Coiled Tubing Drilling Operations. SPE 89334.

Peden, J.M., Ford, J.T. \& Oyeneyin, M.B. 1990 . Comprehensive Experimental Investigation of Drilled Cuttings Transport in Inclined Wells Including the Effects of Rotation and Eccentricity. Paper presented at Europec 90, The Hague, Netherlands. October 22-24.

Rooki, R., Doulati Ardejani, F., Moradzadeh, A. \& Norouzi, M. 2014. Simulation of cuttings transport with foam in deviated wellbores using computational fluid dynamics. Journal of Petroleum Exploration and Production Technology 4(3): 263-273.

Skalle, P. 2011.Drilling Fluid Engineering. Ventures Publishing Aps ISBN $978-87-7681-929-3$.

Sifferman, T.R. \& Becker, T.E. 1992. Hole Cleaning in Full-Scale Inclined Wellbores. SPEDE pp 115-120.

Stan, M. \& Avram, L. 2014. Experimental study on the model of the correlation between the movement of the drilling string with big diameter of drill and effects on the oil rigs. Journal of Petroleum Exploration and Production Technology 1-9.

Tomren, P.H., Iyoho, A.W. \& Azar, J.J. 1986. Experimental Study of Cuttings Transport in Directional Wells. SPE 12123. pp 43-56.

UTM-MPRC Institute for Oil and Gas

Universiti Teknologi Malaysia

81310 UTM Johor Bahru

Malaysia

*Corresponding author; email: issham@petroleum.utm.my

Received: 15 January 2014

Accepted: 1 December 2014 